\title{
Pengaruh Penggunaan LKS Berbantuan Media Phet Terhadap Pemahaman Konsep Meramalkan Bentuk Molekul Pada Siswa Kelas X SMA Negeri 3 Palangka Raya Tahun Ajaran 2018/2019
}

\author{
Wirna Yurinsa $^{1 *}$, Suandi Sidauruk ${ }^{1}$, Karelius ${ }^{1,2}$ \\ ${ }^{1}$ Program Studi Pendidikan Kimia, Universitas Palangka Raya, Indonesia \\ ${ }^{2}$ Program Studi Kimia, Universitas Palangka Raya, Indonesia \\ *E-mail: sriharyatiwulandari123@gmail.com
}

\begin{abstract}
Abstrak
Tujuan penelitian ini adalah untuk mendeskripsikan pengaruh penggunaan LKS berbantuan media PhET terhadap pemahaman konsep meramalkan bentuk molekul pada siswa kelas X SMA Negeri 3 Palangka Raya tahun ajaran 2018/019.

Penelitian ini melibatkan 33 orang siswa kelas X MIPA 5 SMA Negeri 3 Palangka Raya Tahun Ajaran 2018/2019. Instrumen yang digunakan berupa LKS dalam bentuk uraian. Data dikumpulkan melalui 5 tahap pembelajaran dengan menggunakan LKS yakni, pra LKS, saat LKS, pasca LKS, diskusi, dan pasca diskusi. Setiap butir soal yang tersebar memiliki 5 indikator, yaitu konfigurasi elektron dan menentukan elektron valensi, menggambarkan struktur Lewis, menentukan jumlah PEI, menentukan jumlah PEB, menggambarkan bentuk molekul dan menentukan nama bentuk molekul. Kemudian hasil penelitian dianalisis secara deskriptif.

Hasil penelitian menunjukkan bahwa pembelajaran menggunakan LKS berbantuan media PhET mampu meningkatkan pemahaman konsep siswa dalam meramalkan bentuk suatu molekul. Hal tersebut terlihat dari peningkatan pada persentase jawaban benar siswa pada persentase rata-rata dalam setiap tahapan pembelajarannya. Pada saat dilakukannya tahap pra LKS, persentase jawaban benar siswa adalah sebesar 28,19\%. Kemudian konsep siswa mengalami perubahan setelah siswa melalui tahap penggunaan LKS berbantuan media PhET yang mampu merubah persentase pada tahap pasca LKS menjadi 82,61\%. Perubahan persentase jawaban benar pada siswa terus terjadi hingga setelah siswa melewati tahap diskusi yang menunjukkan pada tahap pasca diskusi menjadi $100 \%$ siswa yang mampu memahamai konsep yang benar .
\end{abstract}

Kata Kunci: Lembar Kerja Siswa (LKS), Pengaruh, Media, Bentuk Molekul 


\section{Pendahuluan}

Kimia merupakan salah satu ilmu pengetahuan yang mendasari perkembangan teknologi modern. Kimia disebut juga Central Science kerena perannya yang sangat penting diantara ilmu pengetahuan lain (Purba, 2007). Hampir semua bidang ilmu pengetahuan alam bergantung pada kimia, misalnya pengembangan dalam bidang kedokteran, farmasi, geologi, pertanian dan sebagainya. Selain itu, kimia juga memiliki peranan penting dalam bidang industri karena hampir semua kegiatan industri bergantung pada proses kimia. Demikian pentingnya peranan kimia, sehingga kimia wajib diajarkan di Sekolah Menengah Atas (SMA) sesuai dengan kurikulum yang berlaku, bahkan kimia juga mulai di perkenalkan di Sekolah Menegah Pertama (SMP) agar siswa mempunyai dasar yang cukup untuk melajutkan pelajaran kimia di SMA.

Ilmu kimia mempelajari tentang zat atau reaksi yang berkaitan dengan komposisi, struktur, dan sifat, transformasi, dinamika, energitika zat dengan melibatkan keterampilan dan penalaran (Arifin, 2007).

Penulis melakukan observasi pada saat Praktek Lapangan Kerja (PPL) terhadap siswa kelas X IIS SMA Nusantara Palangka Raya, hasil observasi menunjukan bahwa sebagian besar siswa mengalami kesulitan menuliskan struktur lewis dan meramalkan bentuk molekul pada saat mengerjakan LKS. Berdasarkan permasalahan ini maka siswa harus terlebih dahulu mengetahui konsep-konsep dasar, yaitu mengkonfigurasikan elektron, menuliskan struktur lewis, menentukan pasangan elektron bebas dan pasangan elektron ikatan.

Hasil yang didapat dari serangkaian kegiatan pada kedua observasi tersebut, ternyata menunjukan bahwa siswa cenderung lebih mudah dalam 
meramalkan bentuk molekul suatu senyawa apabila siswa diberikan media molekul interaktif PhET dan siswa melalui tahapan seperti menentukan PEI dan PEB senyawanya dibandingkan saat ujicoba pada siswa yang hanya diberikan soal saja.

Uraian tersebut menjadi latar belakang penulis untuk melakukan penelitian dengan judul "Pengaruh Penggunaan LKS Berbantuan Media PhET Terhadap Pemahaman Konsep Meramalkan Bentuk Molekul pada Siswa Kelas X SMA Negeri 3 Palangka Raya Tahun Ajaran 2018/2019”.

Berdasarkan latar belakang yang di telah dikemukakan di atas, maka rumusan masalah untuk penelitian ini adalah:

Bagaimana Pengaruh Penggunaan LKS Berbantuan Media PhET Terhadap Pemahaman Konsep Meramalkan Bentuk Molekul pada Siswa Kelas X SMA Negeri 3 Palangka Raya Tahun Ajaran 2018/2019?

Penelitian ini bertujuan untuk mendeskripsikan pengaruh penggunaan LKS berbantuan media PhET terhadap pemahaman konsep meramalkam bentuk molekul pada siswa kelas X SMA Negeri 3 Palangka Raya tahun ajaran $2018 / 2019$.

\section{Metodologi Penelitian}

Tahap pelaksanaan penelitian terbagi menjadi 2 waktu pelaksanaan yaitu pelaksanaan uji coba instrumen dan pelaksanaan pengambilan data. Pelaksanaan uji coba instrumen dilakukan pada tanggal 18 Februari 2019 dikelas X IBBU SMA Negeri 3 Palangka Raya dengan jumlah siswa sebanyak 32 orang siswa. Uji coba instrumen dilakukan dengan tujuan untuk melihat kesesuaian waktu, 
keterbacaan instrumen, dan kesesuaian dengan silabus yang digunakan oleh sekolah.

Tahap pelaksanaan pengambilan data dilakukan pada tanggal 20 Februari 2019 di kelas X MIPA 5 SMA Negeri 3 Palangka Raya dengan jumlah siswa sebanyak 33 orang siswa. Pada saat pengambilan data hal-hal yang perlu diperhatikan adalah alokasi waktu pembelajaran harus sesuai dengan pembelajaran dengan pengunaan LKS, diusahakan tidak ada waktu yang terbuang ataupun kurang, lembar instrumen yang dibuat harus sesuai dengan jumlah siswa yang di kelas serta adanya dokumentasi pada setiap tahap pengambilan data yang berlangsung.

a) Tahap Pra LKS, dilakukan dengan cara memberikan tes tertulis. Pada kegiatan ini dibagikan lembar tes dan meminta siswa mengejarkan secara individu dan tidak ada siswa yang membuka buku. Kegiatan ini dilaksanakan 20 menit dan mengerjakan sebanyak 3 soal.

b) Pelaksanaan pembelajaran dengan LKS, dibagikan LKS untuk masingmasing siswa. Pada kegiatan ini hal yang dilakukan oleh guru (peneliti) yaitu membagikan LKS dan tidak memberikan penjelasan materi sehingga siswa belajar dari isi LKS namun siswa diperbolehkan membuka buku untuk mencari informasi menuliskan konfigurasi elektron sampai menggambarkan struktur Lewis dan menggunakan media PhET untuk menentukan jumlah pasangan elektron dan menggambarkan bentuk molekul. Kegiatan ini dilaksanakan 35 menit, mengerjakan 6 soal.

c) Pasca pemberian LKS, dilakukan dengan cara memberikan tes tertulis. Pada kegiatan ini guru membagikan lembar tes dan meminta siswa 
mengerjakan secara individu tanpa membuka buka. Kegiatan ini dilaksanakan selama 25 menit, mengerjakan 3 soal.

d) Diskusi, kegiatan ini dilakukan dengan cara memberikan tes tertulis yang berisi soal pengayaan untuk didiskusikan dalam kelompok. Penentuan jumlah siswa satu kelompok didasarkan pada siswa dengan kemampuan beragam (kemampuan atas, sedang, dan bawah). Kegiatan ini dilaksanakan selam 30 menit, mengerjakan 3 soal.

e) Pasca diskusi, kegiatan ini dilakukan setelah lembar jawaban diskusi dikumpulkan kemudian siswa diberikan lembar diskusi yang lain tetapi dikerjakan secara mandiri. Pada tahap ini siswa mengerjakan 3 soal selama 25 menit.

\section{Hasil Penelitian Dan Pembahasan}

Data hasil penelitian yang terkumpul melalui lembar jawaban siswa dari tiap tahapan pembelajaran menunjukkan hasil jawaban siswa yang beragam dari tiap tahapan. Persentase jawaban siswa pada tahap pra LKS, saat LKS, pasca LKS, diskusi, dan pasca diskusi pada setiap indikator disajikan pada Tabel 7.

Tabel 7. Data Hasil Penelitian Jawaban Benar Siswa dari Pra LKS, Saat LKS, Pasca LKS, Diskusi, dan Pasca Diskusi

\begin{tabular}{lcccccc}
\hline \multirow{2}{*}{ Indikator } & Kelompok & $\begin{array}{c}\text { Pra } \\
\text { LKS } \\
(\%)\end{array}$ & $\begin{array}{c}\text { Saat } \\
\text { LKS } \\
(\%)\end{array}$ & $\begin{array}{c}\text { Pasca } \\
\text { LKS } \\
(\%)\end{array}$ & $\begin{array}{c}\text { Diskusi } \\
(\%)\end{array}$ & $\begin{array}{c}\text { Pasca } \\
\text { Diskusi } \\
(\%)\end{array}$ \\
\hline $\begin{array}{c}\text { 1. Menuliskan } \\
\text { konfigurasi }\end{array}$ & KA & 90 & 100 & 100 & 100 & 100 \\
elektron dan & KS & 49,99 & 100 & 89,74 & 100 & 100 \\
$\begin{array}{l}\text { menentukan } \\
\text { elektron valensi }\end{array}$ & KB & 13,33 & 100 & 73,33 & 100 & 100 \\
$\begin{array}{c}\text { 2. Menggambarkan } \\
\text { struktur Lewis }\end{array}$ & KA & 83,33 & 100 & 96,67 & 100 & 100 \\
& KS & 20,50 & 100 & 76,92 & 100 & 100 \\
& KB & 0 & 100 & 60 & 100 & 100
\end{tabular}




\begin{tabular}{llcclll} 
3. Menentukan & KA & 90 & 100 & 100 & 100 & 100 \\
jumlah pasangan & KS & 15,38 & 100 & 89,74 & 100 & 100 \\
elektron ikatan & KB & 10 & 100 & 73,33 & 100 & 100 \\
$\begin{array}{l}\text { 4. Menentukan } \\
\text { jumlah Pasangan }\end{array}$ & KA & 20 & 100 & 100 & 100 & 100 \\
$\begin{array}{l}\text { elektron bebas } \\
\text { 5. Meramalkan }\end{array}$ & KB & 0 & 100 & 63,33 & 100 & 100 \\
$\begin{array}{l}\text { bentuk molekul } \\
\text { dan menentukan }\end{array}$ & KA & 10 & 100 & 100 & 100 & 100 \\
$\begin{array}{l}\text { nama bentuk } \\
\text { molekul }\end{array}$ & KB & 2,56 & 100 & 80,76 & 100 & 100 \\
\multicolumn{1}{c}{ Rata-rata } & & 0 & 100 & 53,33 & 100 & 100 \\
\hline
\end{tabular}

Persentase jawaban siswa mengalami perubahan konsep ke arah yang benar pada semua indikator dalam setiap tahap pembelajaran. Pemahaman konsep siswa dari tahap pra LKS - pasca LKS semakin meningkat hal ini dapat terjadi karena siswa telah melewati proses pembelajaran pada tahap penggunaan LKS berbantuan media PhET. Media PhET membantu siswa dalam menentukan jumlah pasangan elektron bebas dan jumlah pasangan elektron ikatan yang bertujuan untuk mengetahui konsep awal siswa dalam menentukan salah satu domain elektron. Sedangkan pada indikator menuliskan konfigurasi elektron dan menentukan elektron valensi pemahaman konsep awal siswa terhadap indikator ini memang sudah tinggi, sehingga siswa mampu menjawab sesuai ide sentral.

Merujuk pada Tabel 7, didapatkan data persentase rata-rata jawaban benar siswa dalam setiap tahap pembelajaran yang mencakup seluruh indikator serta data yang menunjukkan persentase rata-rata jawaban benar siswa pada keseluruhan tahap pembelajaran setiap indikator. Berikut grafik yang menunjukkan persentase peningkatan jawaban benar siswa hasil pemebelajaran. 


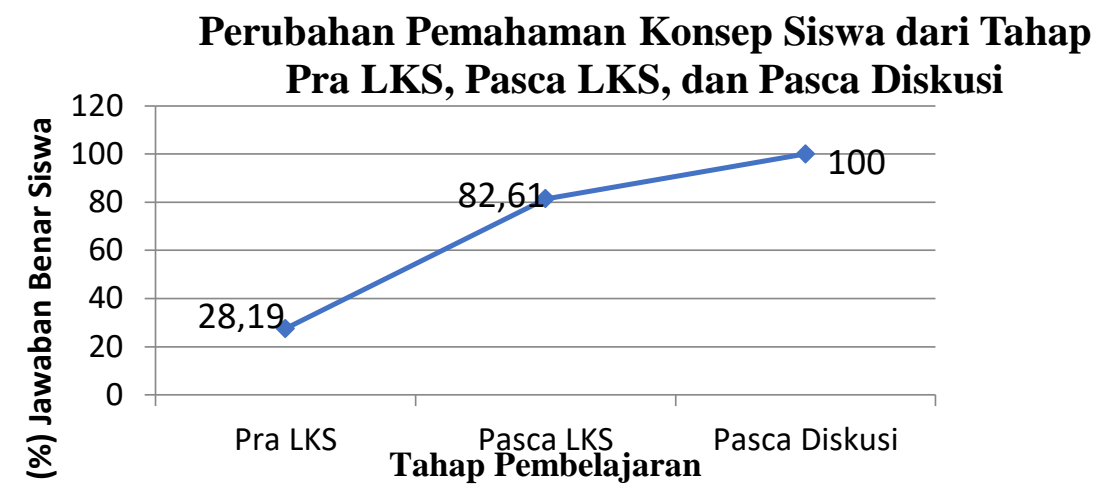

Gambar 14. Persentase Rata-rata Perubahan Konsep Siswa Pada Tahap Pra LKS, Pasca LKS dan Pasca Diskusi

Pada indikator 1 (konfigurasi elektron suatu unsur dan menentukan elektron valensi) pemahaman konsep awal siswa terhadap indikator ini cukup tinggi, yaitu $51,11 \%$ siswa yang mampu menjawab sesuai ide sentral pada tahap pra LKS. Siswa yang masih menjawab salah tersebut memang berada dalam kelompok siswa KS dan KB. Pada tahap pasca LKS, persentase jawaban siswa yang mampu sesuai ide sentral meningkat menjadi $82,61 \%$. Hal ini dapat terjadi karena siswa KS dan KB tersebut telah melewati proses pembelajaran pada tahap penggunaan LKS. Perubahan pemahaman konsep yang terjadi di atas, dapat dinyatakan bahwa penggunaan LKS mampu meningkatkan pemahaman konsep siswa dalam mengkonfigurasi elektron dan menentukan elekton valensi suatu unsur. Pemahaman siswa terhadap konsep ini jug bersifat tetap, ketika siswa diberikan tahapan pembelajaran diskusi yang menunjukkan $100 \%$ siswa mampu menerapkan konsep konfigurasi elektron dan menentukan elektron valensi sesuai ide sentralnya. Hal ini dapat dikarenakan adanya 3 butir soal pada tahap pasca LKS, soal dengan tingkat kesulitan yang sama seperti pada butir soal lainnya tersebut, siswa dapat memperkaya kemampuan yang dimiliki terhadap konsep 
konfigurasi elekton dan menentukan elektron valensi. Berikut Gambar 15 yang menunjukkan perubahan jawaban siswa pada setiap tahap pemebelajaran.

\begin{tabular}{|c|c|}
\hline $\begin{array}{l}\text { Konfigurasi elektron } \\
7 \mathrm{~N}=\ldots .15^{2}+28^{2} .27^{3}\end{array}$ & Penyelesaian : $\longrightarrow \begin{array}{r}\text { Langkah 1: Menuliskan konfiguras } \\
\text { dan menetukan ele }\end{array}$ \\
\hline $\begin{array}{l}{ }_{1} \mathrm{H}=\ldots . \mathrm{IS} \\
\text { Elektrom Zalensi } \\
\mathrm{N}=\ldots \text { (Z. }\end{array}$ & $\begin{array}{l}{ }_{16} S=1 S^{2} 2 S^{2} 2 p^{6} 3 S^{n} 3 P^{4} \text { Elektron valensi } S=6 \\
{ }_{9} F=15^{2} 2 S^{2} 2 p^{5} \quad \text { Elektron valensi } F=7\end{array}$ \\
\hline$H=\ldots \ldots ! \ldots \ldots$ & \\
\hline a. Jawaban saat Pra LKS & b. Jawaban saat penggunaan LKs \\
\hline 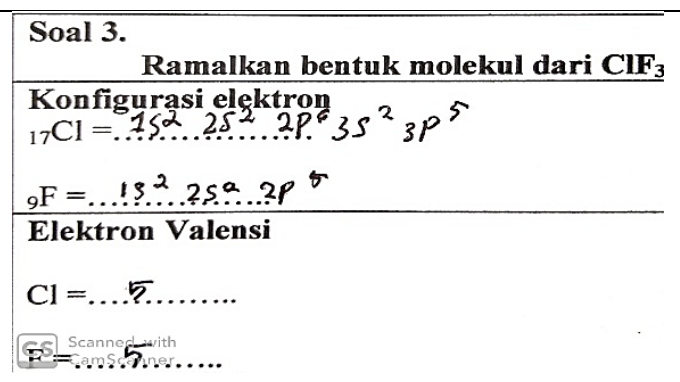 & $\begin{array}{l}\text { Konfigurasi elektron } \\
1 \mathrm{H}=\ldots . \ldots \ldots \ldots \ldots \\
{ }_{8} \mathrm{O}=\ldots . \mathrm{s}^{2} \ldots .2 \mathrm{~S}^{2} \ldots \ldots p^{4} \\
\text { Elektron Valensi } \\
\mathrm{H}=\ldots . \ldots \ldots \ldots \\
\mathrm{O}=\ldots \ldots \ldots \ldots \\
\end{array}$ \\
\hline c. jawaban saat Pasca LKS & d. jawaban saat Diskusi \\
\hline 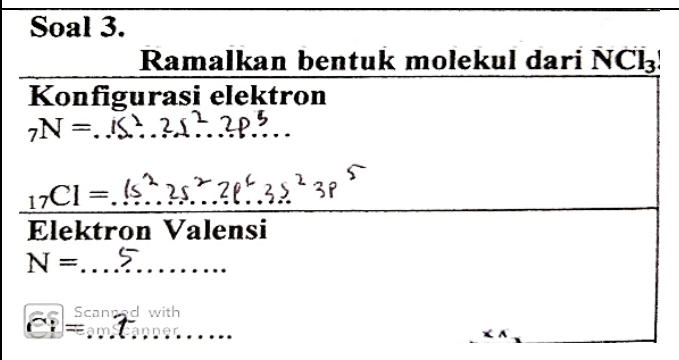 & \\
\hline e. Jawban saat pasca Diskusi & \\
\hline
\end{tabular}

Berdasarkan hasil jawaban siswa pada Gambar 15, dapat disimpulkan bahwa sebagian besar siswa pada tahap pra LKS masih belum dapat mengusai konsep prasyarat untuk meramalkan bentuk molekul, namun setelah melalui proses pembelajaran pada tahap saat LKS dan Diskusi, pemahaman konsep siswa menuju ke arah yang benar. 
Pada indikator 2 (menggambarkan struktur Lewis) diperoleh hasil bahwa terjadi peningkatan persentase jawaban benar sebesar 43,25\% yaitu dimana saat pra LKS jumlah jawaban benar siswa sebanyak 34,61\% meningkat menjadi 77,86\% pada saat pasca LKS. Hal ini dikarenakan siswa sudah melewati tahap penggunaan LKS. Berdasarkan hasil tersebut dapat disimpulkan bahwa tahap penggunaan LKS mampu meningkatkan pemahaman siswa terhadap konsep menggambarkan struktur Lewis. Peningkatan jumlah siswa yang menjawab benar tersebut menunjukkan hasil belajar yang didapat siswa diperoleh setelah siswa menempuh proses atau pengalaman belajarnya.

\begin{tabular}{|c|c|}
\hline $\begin{array}{c}\text { Struktur Lewis } \mathrm{NH}_{3} \\
: H: \ddot{N}: H \\
\ddot{H}\end{array}$ & $\underbrace{}_{\substack{\text { CS Scanne } \\
\text { Camscann }}}$ \\
\hline a. Jawaban saat Pra LKS & b. Jawaban saat penggunaan LKs \\
\hline 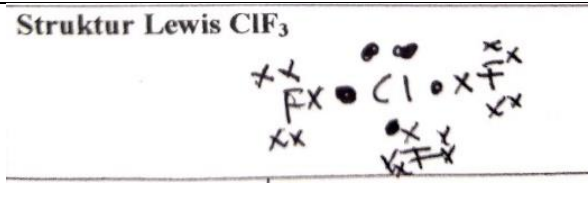 & 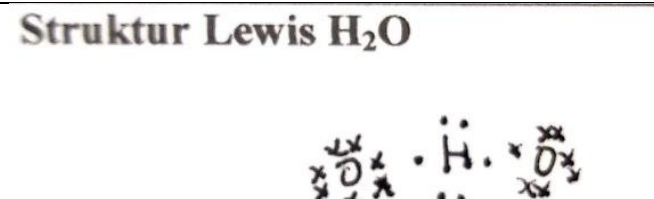 \\
\hline c. jawaban saat Pasca LKS & d. jawaban saat Diskusi \\
\hline 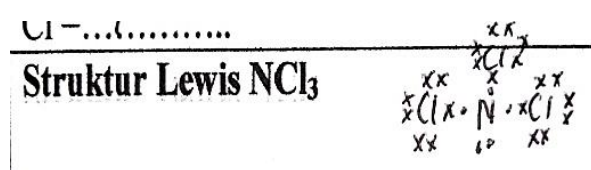 & \\
\hline e. pasca diskusi & \\
\hline
\end{tabular}


Selanjutnya adalah data jawaban siswa pada indikator 3, hasil yang ditunjukkan dalam menentukan jumlah pasangan elektron ikatan (PEI) adalah $38,46 \%$ yaitu siswa KA yang mampu menjawab sesuai ide sentral pada tahap pra LKS. Kemudian setelah tahap penggunaan LKS berbantuan media PhET dilewati siswa, kemampuan siswa meningkat sebesar menjadi $81,53 \%$ pada tahap pasca LKS. Hal ini menunjukkan terjadi peningkatan dimana siswa KS dan KB telah mampu menerapkan hasil dari proses belajarnya saat penggunaan LKS berbantuan media PhET terutama pada konsep PEI.

Peningkatan pemahaman konsep siswa dalam menentukan jumlah pasangan elektron ikatan terus mengalami peningkatan dari tahap pra LKS Pasca Diskusi, hal tersebut ditunjukkan dengan persentase jawaban benar yang meningkat sebanyak $18,47 \%$. Persentase ini menunjukkan pada tahap tahap Diskusi mampu membuat siswa KB menenerapkan konsep penentuan jumlah PEI dengan baik, sehingga pada tahap pasca Diskusi dapat dikatakan mempertajam kemampuan siswa dalam menguasai dan menerapkan konsep menentukan jumlah pasangan elektron ikatan. Selain itu peningkatan yang terjadi juga menunjukkan bahwa hasil belajaryang didapat siswa diperoleh setelah siswa menempuh proses atau pengalaman belajarnya. 


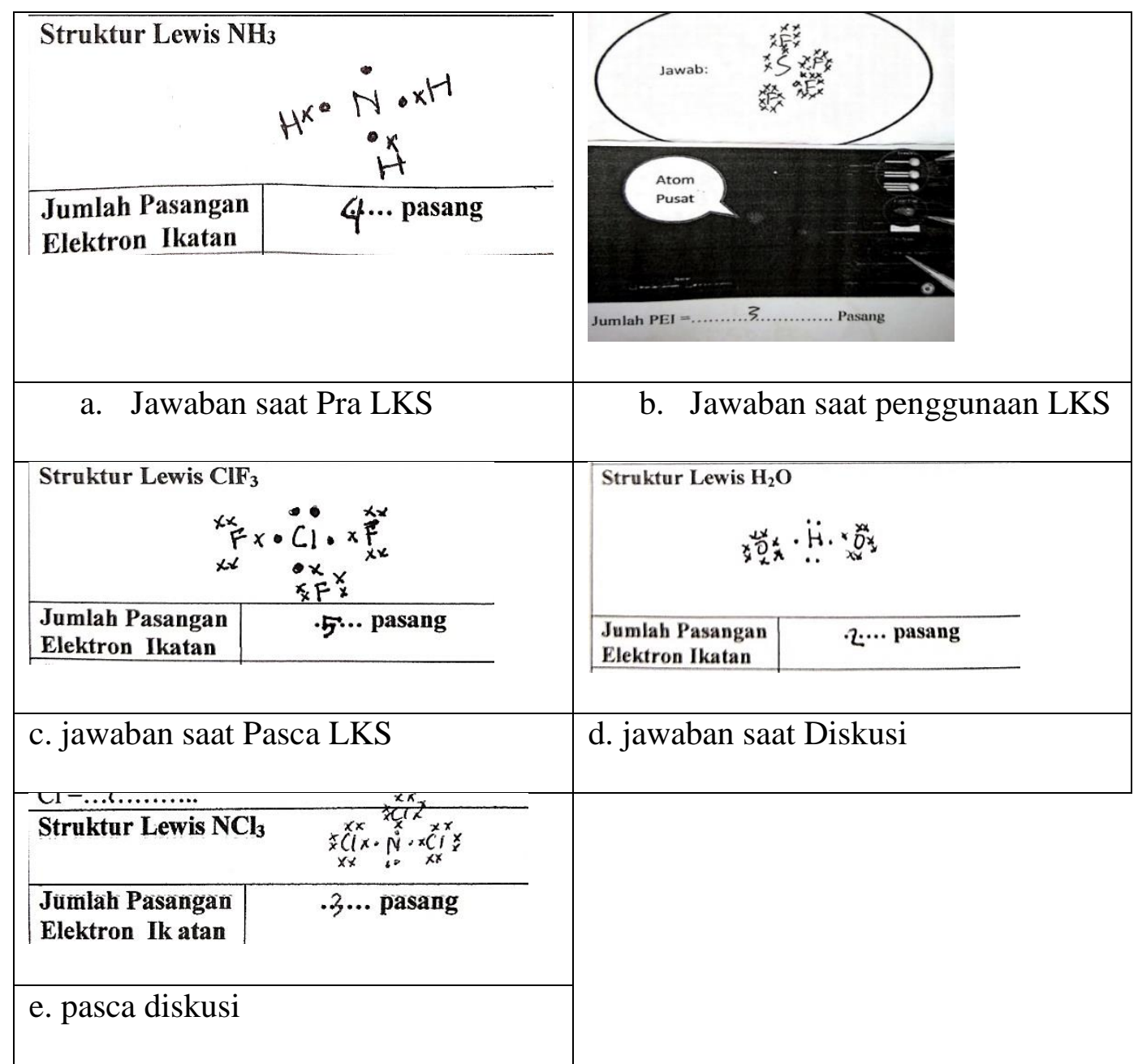

Gambar 17. Perubahan Jawaban Siswa Dalam Menentukan Jumlah PEI

Berikut Gambar 18 jawaban siswa menentukan jumlah PEI senyawa $\mathrm{SF}_{4}$ menggunakan media PhET.

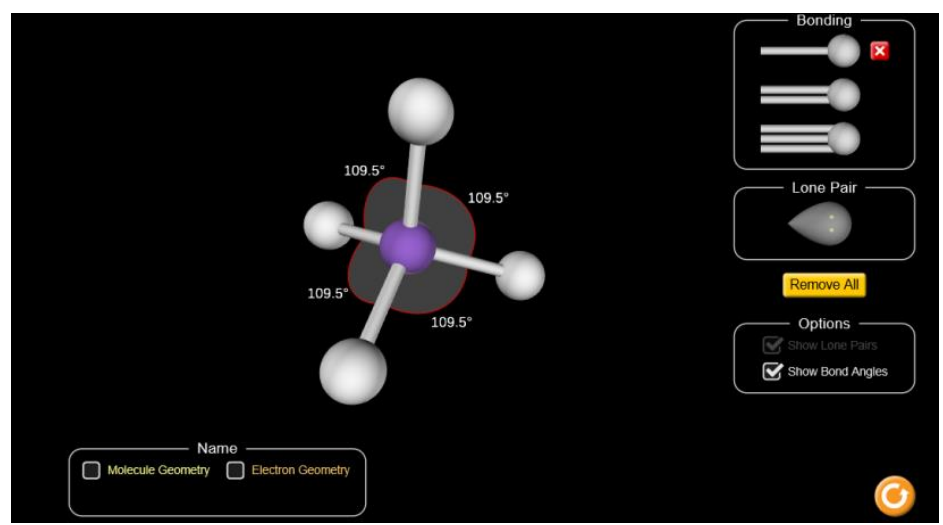

Gambar 18. Jawaban siswa menentukan PEI menggunakan Media PhET 
Menggunakan media PhET siswa dapat menentukan jumlah PEI dengan benar dan siswa juga bisa melihat sudut ikatan yang terbentuk antar PEI - PEI. Bentuk molekul secara 3 dimansi memberikan gambaran bentuk molekul secara nyata bagi siswa sehingga siswa bisa merangkai sendiri bentuk molekul dari senyawa $\mathrm{SF}_{4}$.

Data hasil jawaban siswa selanjutnya adalah data siswa pada indikator 4 . Hasil yang ditunjukkan dalam menentukan jumlah pasangan elektron bebas hanya 9,23\% yaitu siswa KA yang mampu menjawab sesuai ide sentral pada tahap pra LKS. Kemudian setelah tahap penggunaan LKS berbatuan media PhET dilewati siswa, kemampuan siswa meningkat menjadi $81,79 \%$ pada tahap pasca LKS. Hal tersebut menunjukkan peningkatan sebesar $72,56 \%$, dimana siswa KS dan $\mathrm{KB}$ telah mampu menerapkan hasil dari proses belajarnya saat penggunaan LKS berbantuan media PhET pada konsep menentukan jumlah PEB. Berikut perubahan jawaban siswa dalam menentukan pasangan elektron bebas.

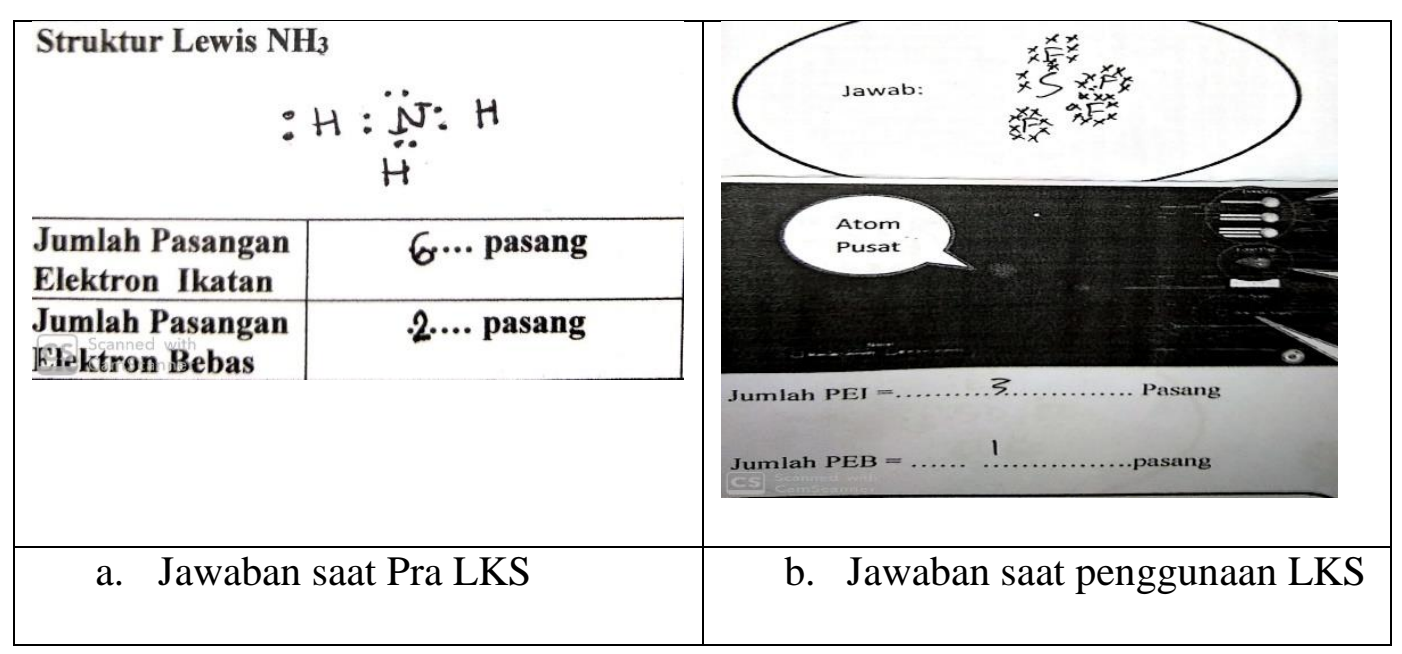




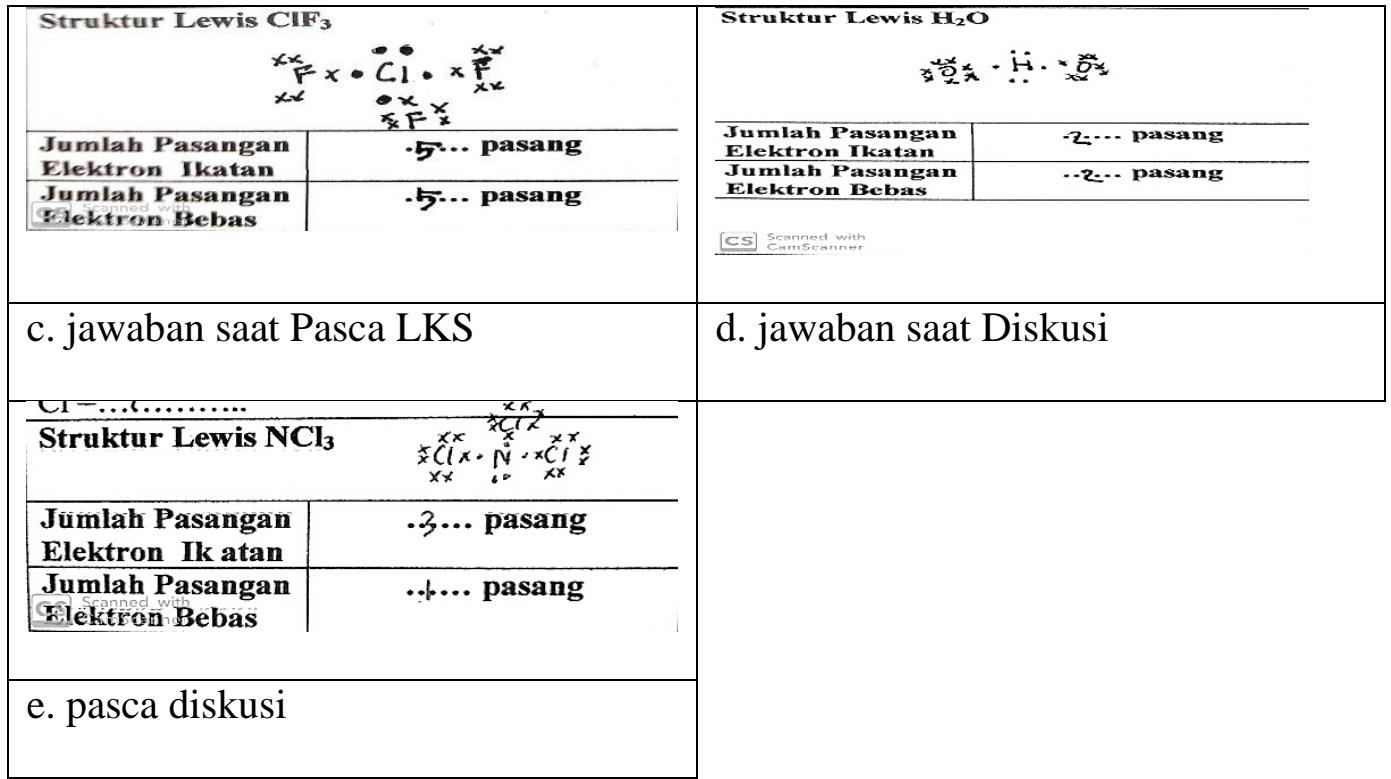

Berikut Gambar 20 menunjukkan hasil jawaban siswa saat penggunaan LKS berbantuan media PhET dalam menentukan jumlah pasangan elektron bebas senyawa $\mathrm{SF}_{4}$.

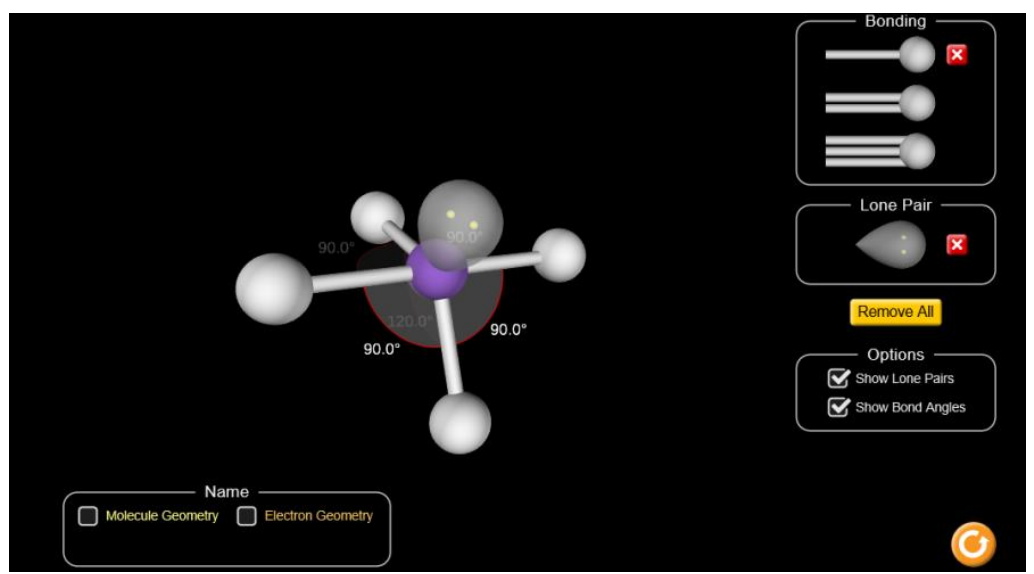

Gambar 20. Jawaban Siswa Menentukan PEB Menggunakan Media PhET

Gambar 20 menunjukkan domain-domain elektron sehingga menggambarkan bentuk molekul suatu senyawa. Melalui media PhET siswa merangkai sendiri jumlah PEI dan PEB sehingga membentuk geometri molekul senyawa SF4. Adanya pasangan elektron bebas pada kulit valensi atom pusat dapat memperkecil sudut-sudut ikatan sekitar atom pusat (Chang, 2005). 
Peningkatan pemahaman konsep siswa selanjutnya yaitu menggambarkan bentuk molekul dan menentukan nama bentuk molekul pada tahap pra LKS pasca Diskusi. Peningkatan yang terjadi sangatlah signifikan, hal tersebut terlihat dari data hasil persentase jawaban siswa (Tabel 7 halaman 44). Peningkatan yang terjadi adalah sebesar $73,84 \%$ pada tahap pra LKS - Pasca LKS, hal tersebut menunjukkan bahwa siswa KA, KS dan KB telah menerapkan konsep menggambarkan bentuk molekul dan menentukan nama bentuk molekul. Perubahan konsep yang terjadi karena telah dilaluinya tahap penggunaan LKS bebatuan media PhET. Berikut gambar perubahan jawaban benar siswa.

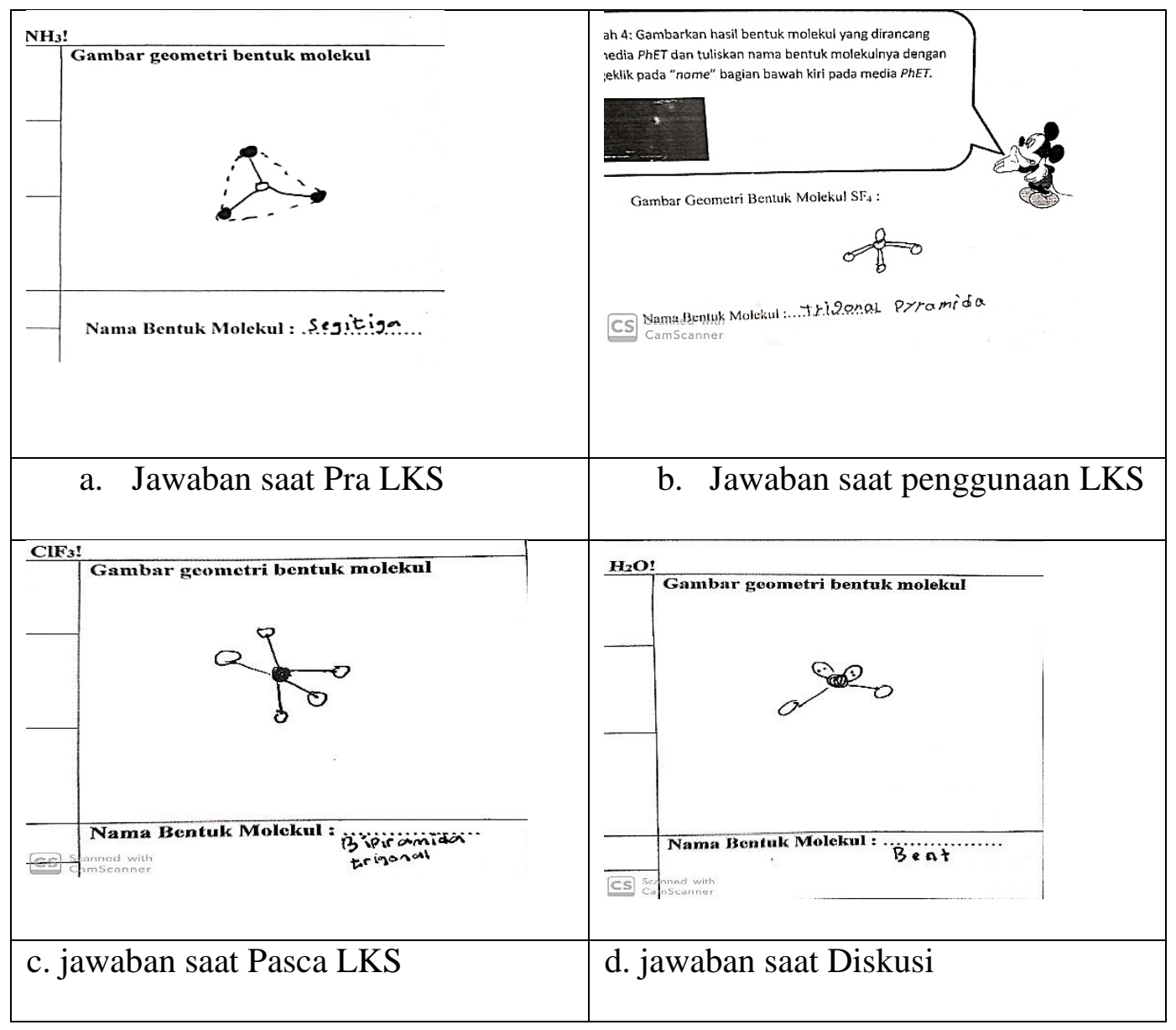




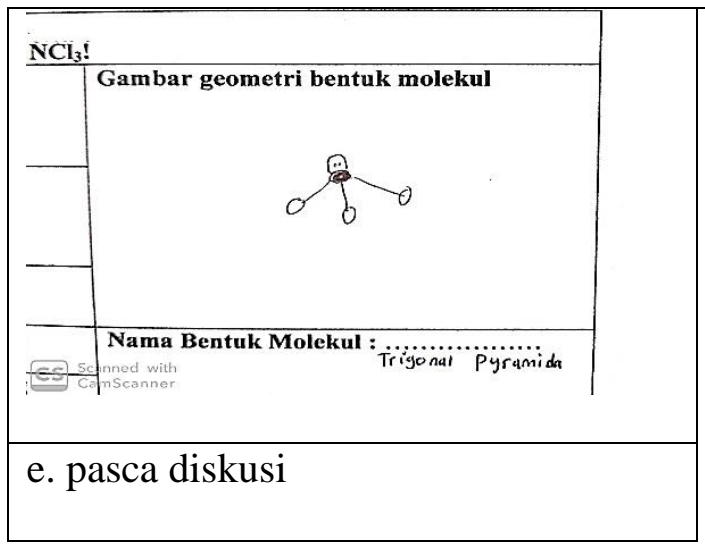

Perubahan konsep siswa ini dipengaruhi oleh adanya langkah-langkah penyelesaian dalam LKS dan dengan adanya bantuan media PhET yang membantu siswa dalam menyelesaikan soal-soal dalam LKS. Berikut Gambar 22 hasil jawaban siswa menggunakan media PhET dalam menentukan bentuk molekul dan nama bentuk molekul.

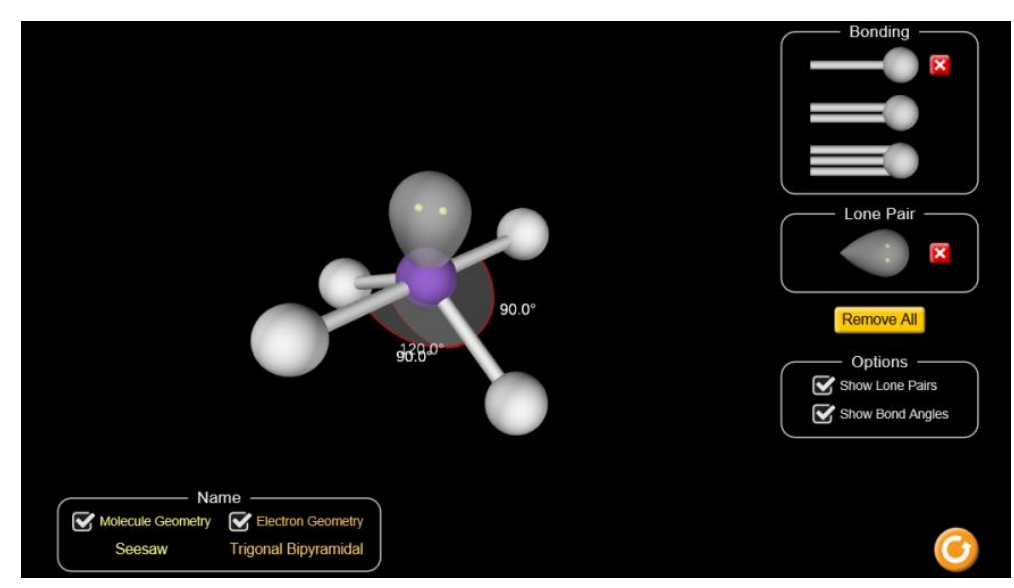

Gambar 22. Jawaban Siswa Menggambarkan Bentuk Molekul dan Menentukan Nama Bentuk Molekul Menggunakan Media PhET

\section{Simpulan}

Hasil penelitian menunjukkan bahwa pembelajaran dengan menggunakan LKS berbatuan media PhET mampu meningkatkan pemahaman konsep siswa dalam meramalkan bentuk molekul. Terjadi peningkatan persentase jawaban 
benar siswa dari tahap pra LKS - pasca LKS sebesar 54, 42\% dan setelah pelaksanaan diskusi persentase jawaban siswa meningkat dari tahap pasca LKS pasca diskusi sebesar 17,39\%. Siswa mengalami perubahan konsep meramalkan bentuk molekul dengan proses: menuliskan konfigurasi elektron dan menentukan elektron valensi sebesar 79,6\%, menggambarkan struktur lewis sebesar 70,82\%, menentukan jumlah pasangan elektron ikatan sebesar 73,33\%, menentukan jumlah pasangan elektron bebas sebesar 63, 67\%, menggambarkan bentuk molekul dan menentukan nama bentuk molekul sebesar 60,74\%. Media PhET tersebut menciptakan pembelajaran Kimia yang aktif, kreatif, efektif, dan menyenangkan. Pengetahuan baru yang dipelajari oleh siswa yaitu gambaran fisik dari bentuk molekul yang ditentukan oleh jumlah pasangan elektron ikatan dan jumlah pasangan elektron bebas, sehingga besar sudut-sudut ikatan yang ada disekitar atom pusat mengecil karena tolakan dari pasangan elektron beba.

\section{Daftar Referensi}

Arifin, M. 2003. Strategi Belajar dan Mengajar Kimia. Bandung : Universitas Pendidikan Indonesia.

Arifin, M. 2007. Pengembangan Kurikulum dan Pembelajaran Kimia. Jakarta : Universitas Terbuka.

Suharsimi, A. 2009. Dasar-dasar Evaluasi Pendidikan. Jakarta : Rineke Cipta.

Arsyad, A. 2004. Media Pemebelajaran. Jakarta: Raja Grafindo Perkasa.

Elva S., Liliasari, \& Rohman, I. 2014. Pengembangan Keterampilan Berpikir Kritis Siswa SMA Pada Topik Toeri Domain Elektron Melalui Simulasi Interaktif PhET Molecule Shapes. Jurnal Pengajaran MIPA, 19 (2). 
Indriyani, L. 2016. Pengaruh Penggunaan Simulasi PhET dengan Model Problem Solving terhadap Minat Belajar Siswa pada Pembelajaran tentang Hukum Boyle dan Gay Lussac di Kelas XI IPA SMA 1 Prambanan dan SMA Negeri 2 Kalaten. Yogyakarta : Universitas Sanata Dharma Yogyakarta.

Irianti, N. 2011. Pengaruh Penggunaan LKS Terhadap Kemampuan Visualisasi Molekul Pada Siswa Kelas XI IPA-1 IPA SMA Negeri 3 Palangka Raya Tahun Ajaran 2010/2011. Skripsi Tidak diterbitkan. Palangka Raya : FKIP UNPAR.

KBBI. 2007. Kamus Bahasa Indonesia. Jakarta. Balai Pustaka.

Makmun, A. S. 2007. Psikologi Pendidikan. Bandung : PT Remaja Rosdakarya.

Meyasi, Y. 2015. Kesulitan Siswa Kelas X SMA Negeri 1 Marung dan SMA Negeri 1 Gunung Timang Tahun 2014/2015 dalam Memahami Hukumhukum Dasar Kimia. Palangka Raya: Universitas Palangka Raya.

Michael, P. 2017. Kimia Kelas I. Jakarta: Erlangga.

Muhammad, A. Pengaruh Penerapan Media Pembelajaran PhET (Phsycs Education Technology) Simulation Terhadap Hasil Belajar Siswa Kelas X Titl Pada Standar Kompetensi Mengaplikasikan Rangkaian Listrik di SMKN 7 Surabaya. Jurnal Pendidikan Teknik Elektro. Volume 04 Nomor 02 Tahun 2005.

Nopriliani. 2017. Kesulitan Siswa Memahami Konsep Meramalkan Bentuk Molekul Pada Siswa Kelas X MIA SMA Negeri di Kota Palangka Raya Tahun Ajaran 2017/2018. Plangka Raya :Universitas Palangka Raya. 
Wirna Yurinsa (264-281)

Permatasari, Devi. 2016. Jurnal Indafi Pengaruh Model Discovery Learning Berbantuan Model PhET Terhadap Hasil Belajar. Medan : Universitas Negeri Medan.

Purba, M. 2007. Kimia untuk SMA Kelas X. Jakarta : Erlangga.

Petrucci, R. H. 1997. Kimia Dasar Prinsip dan terapan Modern Edisi Keempat Jilid I. Jakarta: Erlangga.

Qomariah, D. 2016. Kesulitan Siswa Kelas XI IPA SMA Palangka Raya Tahun Pelajaran 2015/2016 dalam Memahami Konsep-konsep Dasar Ikatan Kimia. Palangka Raya : Universitas Palangka Raya.

Rusliana, L. 2017. Kesulitan Pemahaman konsep Persamaan Termokimia pada Siswa Kelas XI SMA Negeri di Palangka Raya Tahun Ajaran 2016/2017. Palangka Raya: Universitas Palangka Raya.

Sujanto, B. 2007. Guru Indonesia dan Perubahan Kurikulum. Jakarta : Sagung Seto.

Supartini, E. 2001. Diagnosa Kesulitan Belajar dan Pengajaran Remedial. Yogyakarta: Fakultas Ilmu Pendidikan Ilmu Pendidikan Universitas Negeri Yogyakarta. 